\title{
A revision of Solanum brownii Dunal (Solanaceae) and its allies
}

\author{
A.R. Bean
}

\begin{abstract}
Bean, A.R. (Queensland Herbarium, Brisbane Botanic Gardens, Mt Coot-tha Road, Toowong, Qld 4066, Australia) 2001. A Revision of Solanum brownii Dunal (Solanaceae) and its allies. Telopea 9(3): 639-661. A taxonomic revision of taxa previously identified as Solanum brownii, S. cinereum, S.amblymerum or S. elegans is presented. This group is distributed from far eastern Victoria to southeastern Queensland. Ten species are here recognised, with six species described as new (S. armourense, S. celatum, S. limitare, S. neoanglicum, S. nobile and S. silvestre) and two (S. amblymerum and S. curvicuspe) reinstated. A lectotype is chosen for S. curvicuspe. Solanum elegans is shown to be a synonym of $S$. brownii. Illustrations, distribution maps and an identification key to species are provided.
\end{abstract}

\section{Introduction}

In 1803-04, Robert Brown collected a number of Solanum specimens from the Sydney and Hunter Valley areas of New South Wales. He subsequently (Brown 1810) described several species on the basis of these specimens, including Solanum cinereum and S. violaceum; S. violaceum R.Br. is a later homonym of S. violaceum Ortega, and hence an illegitimate name. $M$. Dunal provided the new name $S$. brownii for this species in 1813, and soon after (Dunal 1814) described S. elegans as new. A related but distinctive entity, S. amblymerum, was subsequently described by Dunal (1852).

Bentham (1868) and subsequent workers applied the name S. brownii to a wide range of material from throughout New South Wales. However, Domin (1913) excised a new species, Solanum curvicuspe, from S. brownii (sensu Bentham) after examining material at Kew, although it seems his species was not accepted by any other contemporary botanist.

Symon (1981) accepted S. cinereum, treated S. brownii in its traditional broad circumscription, and reduced S. amblymerum to a synonym of S. elegans Dunal.

The highly variable nature of $S$. brownii sens. lat. and confusion between it and S. cinereum and S. amblymerum (S. elegans sensu Symon) prompted the current study, and it was soon realised that several taxa are involved.

In this paper, $S$. brownii and $S$. cinereum are maintained with narrower circumscriptions; S. amblymerum and S. curvicuspe are reinstated, S. elegans is shown to be a synonym of $S$. brownii, and six new species are described. All of these species belong to the large Solanum subg. Leptostemonum, which includes all prickly species, and has a world-wide distribution. 


\section{Materials and methods}

This study was based mainly upon a morphological study of herbarium material from BRI, MEL, NSW, as well as types from AD, K and BM. In addition, all taxa have been examined in the field, with the aim of observing and recording juvenile characteristics, habitat, size and colour of mature fresh fruits, variation within and between populations, and to collect spirit material of flowers and fruits for later examination.

\section{Morphological characters and terminology}

Juvenile plants belonging to Solanum subg. Leptostemonum are invariably more densely prickly (stems and leaves) and have larger, more deeply lobed leaves than the adult plants of the same species (Roe 1966, Symon 1981, pers. obs.). Young vigorous plants flowering for the first time may bear branches and leaves that are still somewhat juvenile in character. Juvenile growth may also be found on mature-sized plants, where a vigorous shoot arises from a lower part of the plant.

The density of prickles on branchlets (both juvenile and adult) is taxonomically useful. For this measurement, the one decimetre section between 1 and $2 \mathrm{dm}$ from the growing point was chosen.

Many species of Solanum have leaves which are asymmetrical (or oblique) at their base. The obliqueness index, used here, is simply 100 times the length of the oblique section divided by the length of the lamina, i.e. $100 \times \mathbf{b} /(\mathbf{a}+\mathbf{b})$ on Fig. 1. Petiole length is expressed as a percentage of lamina length i.e. $100 \times \mathbf{c} /(\mathbf{a}+\mathbf{b})$ on Fig. 1. Leaf length/width ratio is $(\mathbf{a}+\mathbf{b}) / \mathbf{d}$.

The degree of lobing of the adult leaves is diagnostic. The lobing index, used here, is the length of the lobe halfway along the lamina (measured along the lateral vein) divided by the parallel length of the adjacent sinus, i.e. $\mathbf{f} / \mathbf{e}$ on Fig. 1 . The index is 1 for an entire leaf; leaves with an index $>2$ are considered to be deeply lobed.

Stellate hairs are a feature of all species in the group (and in the majority of Solanum species in Australia). Their size, form, colour, density etc. are all very useful for taxonomic purposes, but their usefulness is complicated by the fact that often a bewildering array of constructions are present on the one plant (Seithe 1979). For example, the stellate-hair pattern observed on the branchlets is different to that observed on the upper leaf surface. However the indumentum pattern for a given plant part for a given species is consistent. The term 'stellae' is a collective term used to denote the members of the 'stellate hair' indumentum type, as was done by Whalen et al. (1981).

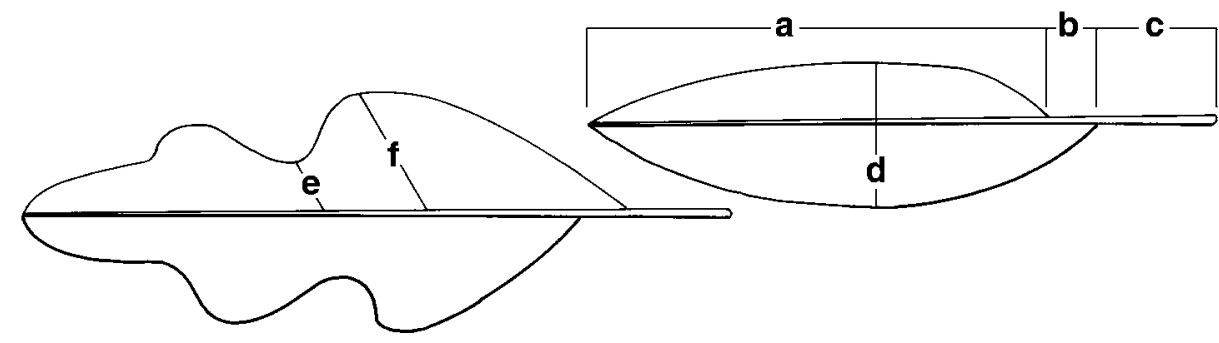

Fig. 1. Diagrammatic representation of leaves showing measurements used. 
The following terminology is used here for stellate hair density: very dense: stellae overlapping, multi-layers, underlying surface not visible dense: stellae overlapping, single layer only, underlying surface visible moderate: stellae just or not overlapping, cores 1-2 diameters apart sparse: stellae not overlapping, cores $2-4$ diameters apart

very sparse: stellae not overlapping, cores $>4$ diameters apart.

Foliage indumentum characters were assessed on fully expanded leaves only. With respect to stellate hairs, more than one developmental stage is apparent on the upper leaf surface of most species. It is the modal size class that was recorded and measured for each species. Hence very small imperfectly developed stellae were not measured, nor were exceptionally large stellae.

In all species of the group, the inflorescences are andromonoecious. That is, the first formed (basal) flowers are bisexual, but the terminal flowers are effectively male, as they have a very short non-functional style.

The type and extent of indumentum present on the ovary and style is diagnostic for species in this group.

The colour, shape and size of mature Solanum fruits are all important taxonomic characters, but all difficult to assess from herbarium material. My field studies have shown that all species in the S. brownii complex have globular or slightly oblate fruits which, at maturity, range in diameter from $13 \mathrm{~mm}$ (for S. silvestre) to $29 \mathrm{~mm}$ (for S. brownii). Furthermore, mature fruits of all species are green or greenish-white, although over-mature fruits may become pale yellow. In the field, fruits are assessed as mature when either they achieve a yellowish tint and become softer, or they shed from the plant at the slightest touch.

Out of approximately 400 herbarium specimen labels examined in this study, I saw only one where the fruit was stated to be red (North Obelisk, Urbenville, Constable 6646 (NSW)). This was certainly an error on the part of the collector, but appears to be the basis for Symon (1981) attributing a red fruit colour for S. elegans, and was perhaps his reason for placing $S$. elegans in a position far removed from $S$. brownii and S. cinereum in his classification.

The closest relative of the group is probably S. tetrathecum F. Muell. It differs from the $S$. brownii group by the smaller, deeply lobed corolla, the ribbed hypanthium and very short calyx lobes.

Entire-leaved members of the $S$. brownii group are sometimes confused with S. stelligerum $\mathrm{Sm}$., however, the latter is readily distinguished by the much longer hairs on the lower leaf surface, the slender pedicels, the smaller deeply-lobed corolla, and the smaller succulent fruit, bright-red at maturity.

\section{Conservation aspects}

Many of the taxa documented herein are considered to be rare or threatened, for the following reasons:

1. competition for light, water and nutrients with weeds, especially Lantana camara. Several of the Solanum species in this group grow on rainforest margins where Lantana is abundant.

2. extremely low frequency and/or population levels. Many solanums may have a brief large increase in numbers after a suitable disturbance event, but generally population levels are very low. IUCN recommends that conservation assessments be based on the lowest numbers. Changes in land use pattern, and fire regimes have 
seen a decline in frequency of solanums, and probably their ability to recolonise if conditions are again favourable.

3. deliberate destruction by ignorant people who think that any prickly plant is a weed. While this factor is not a major one, neither is it inconsequential. Solanums often inhabit roadsides and clearings where there is extra light, and often they are able to flower and fruit only in these situations. These areas are frequently subject to weed eradication measures, and native solanums often suffer during these operations.

\section{Taxonomic treatment}

\section{The 'S. brownii group'}

Erect perennial shrubs (or probably annual for S. limitare); prickles present, sparse to moderately dense, always straight and acicular; sympodia difoliate. Bark smooth, nondescript. Stellate hairs present, rays not bent or twisted, central rays without glandular tips. Simple hairs absent. Stipitate glands absent except on style and ovary. Juvenile leaves conspicuously and often deeply lobed. Adult leaves entire to deeply lobed; upper surface green to grey-green, sparsely to densely stellate-tomentose; lower leaf surface canescent, white to pale yellow, very densely stellate-tomentose, stellae usually completely obscuring leaf surface. Inflorescence supra-axillary, pseudoracemose, andromonoecious (with male flowers in the terminal parts), axis present. Corolla 5-partite, rotate to shallowly lobed, purple (rarely white), 15-35 mm across. Anthers all similar, glabrous. Ovary 2-locular, ovary and style with stipitate glands (except $S$. cinereum), and sometimes with stellate hairs. Fruits pale green with darker green streaks or blotches, greenish-white at maturity, pericarp thick, surface usually glabrous. Calyx in fruit not noticeably accrescent.

Group comprises 10 species from south-eastern mainland Australia.

\section{Key to species of the Solanum brownii group}

1 Adult leaves conspicuously lobed (lobing index 1.7-4.8)

2 Calyx bearing 20-40 prickles; ovary glabrous 1. S. cinereum

2* Calyx unarmed or with up to 5 prickles; ovary with stipitate glands 2. S. nobile

1* Adult leaves entire or with shallow lobes (lobing index 1-1.5)

3 Upper leaf surface (except veins) very sparsely to sparsely hairy (stellae not overlapping)

4 Leaves broad-lanceolate, 2.5-3.4 times longer than broad, upper surface not wrinkled 7. S. silvestre

$4^{*}$ Leaves linear to lanceolate, 3.5-13 times longer than broad, upper surface usually wrinkled

5 Lower leaf surface with loose, thick tomentum; central ray of stellae on upper leaf surface 1-2 times as long as lateral rays; functional style $8.5-10 \mathrm{~mm}$ long

\section{S. brownii}

$5^{*}$ Lower leaf surface with close, thin tomentum; central ray of stellae on upper leaf surface $0-0.5$ times as long as lateral rays; functional style $10-12 \mathrm{~mm}$ long

6 Calyx lobes attenuate; pedicels 11-20 mm long at anthesis; stellae of upper leaf surface $0.2-0.4 \mathrm{~mm}$ across; stellae on the style with 13-20 lateral rays

6. S. limitare

6* Calyx lobes deltate; pedicels 5-10 mm long at anthesis; stellae of upper leaf surface $0.1-0.2 \mathrm{~mm}$ across; stellae on the style with 9-10 lateral rays 
3* Upper leaf surface moderately to very densely hairy (stellae overlapping)

7 Functional style $6.5-7 \mathrm{~mm}$ long; corolla $15-18 \mathrm{~mm}$ across; upper leaf surface stellae $0.1-0.15 \mathrm{~mm}$ across 8. S. armourense

$7^{*}$ Style 7.5-12 mm long; corolla 18-32 mm across; upper leaf surface stellae 0.15$0.4 \mathrm{~mm}$ across

8 Lower leaf surface tomentum 'loose', obscuring tertiary venation; functional style $7.5-9 \mathrm{~mm}$ long

9 Leaves $0.3-1.5 \mathrm{~cm}$ wide, 6-10 times longer than wide; anthers $4-5 \mathrm{~mm}$ long 10. S. neoanglicum

9* Leaves $1.5-3.5 \mathrm{~cm}$ wide, 2.6-3.6 times longer than wide, anthers 5-6.5 $\mathrm{mm}$ long 9. S. celatum

$8^{*}$ Tertiary venation readily visible on lower leaf surface, tomentum 'close'; functional style 9-12 mm long

10 Style bearing stellate hairs; stellae of upper leaf surface $0.2-0.4 \mathrm{~mm}$ diameter; subshrub to $80 \mathrm{~cm}$ high, from eucalypt forest 6. S. limitare

$10^{*}$ Style glabrous or bearing stipitate glands; stellae of upper leaf surface $0.15-0.2 \mathrm{~mm}$ diameter; tall shrub to $3 \mathrm{~m}$ high, from rainforest

3. S. curvicuspe

1. Solanum cinereum R.Br., Prodr. 446 (1810).

Type: New South Wales: "banks of the Grose [River], 1804 [Oct/Nov 1803]", R. Brown (holo BM).

Shrub 0.3-0.7 m high. Fertile branchlets terete, mauve to grey, tomentose, with dense (branchlet visible) or very dense (branchlet obscured) stellate hairs, densely armed with prickles (17-60 per $\mathrm{dm}$ of branchlet) each 3-10 $\mathrm{mm}$ long, glabrous; stellae variably stipitate, $0.35-0.5 \mathrm{~mm}$ across, lateral rays $8-14$, central ray $0.5-1$ times as long as laterals. Juvenile leaves lyrate-pinnatifid, 5-9.5 cm long, 4-9 cm wide, densely prickly. Adult leaves ovate in outline, deeply lobed, lobes 3-5 on each side, obtuse or acute, lobing index 2.7-4.8; lamina 5.3-12.4 cm long, 3.5-5.7 cm wide, 1.4-2.4 times longer than broad, apex acute or obtuse, often basally dimidiate, oblique part $0-12 \mathrm{~mm}$ long, obliqueness index 0-12\%. Petioles (1.1-)1.7-3.3 cm long, (13-)20-47\% length of lamina, prickles present. Upper leaf surface green, flat between major veins; prickles present on midvein and secondary veins; stellae very sparse (cores 0.9-2.5 mm apart), distributed throughout lamina or confined to major veins, $0.2-0.4 \mathrm{~mm}$ across, sessile or shortly stalked, lateral rays 6-8, central ray 1-2 times as long as laterals. Lower leaf surface white to pale yellow, prickles present on midvein and secondary veins; stellae densely packed in several layers, obscuring leaf surface, $0.4-0.7 \mathrm{~mm}$ across, mostly long-stalked (loose tomentum), lateral rays 7-8, central ray 0.5-1.5 times as long as laterals. Inflorescence pseudo-racemose, axis present, 3-6-flowered, prickles present on axis and pedicels; pedicels 7-16 mm long at anthesis. Calyx densely stellate-hairy, stellae $0.4-0.5 \mathrm{~mm}$ across, transparent or purple, lateral rays $7-11$, central ray $0-0.5$ times as long as laterals. Prickles 20-40 per flower, scattered; hypanthium campanulate, 2.5-3.8 mm long at anthesis; lobes attenuate, $2.5-4 \mathrm{~mm}$ long at anthesis. Corolla rotate, purple, 22-30 mm across. Filaments $0.5-0.9 \mathrm{~mm}$ long, glabrous; anthers $4.1-5.5 \mathrm{~mm}$ long. Ovary surface glabrous; functional style $9-10 \mathrm{~mm}$ long, erect, with stellate hairs on the proximal half; stigma entire. Mature fruits 1-4 per inflorescence, globular, pale green to greenish-white, 17-24 mm diameter, pericarp 2-2.5 $\mathrm{mm}$ thick when fresh, surface glabrous or with a few scattered stellate hairs. Fruiting calyx not noticeably accrescent. Pedicels 15-27 mm long in fruit. Seeds brown to black, 3.2-3.5 mm long. 
Notes: From the excellent paper by Vallance (1990), it is deduced that Robert Brown collected the type of S. cinereum in October or November of 1803, rather than the '1804' indicated by Brown's label. Vallance (loc. cit.) noted that it was not uncommon for Brown to make errors with respect to collection dates.

Distribution: S. cinereum is widely distributed on the western slopes of the Great Dividing Range from Stanthorpe (Qld) to Albury (NSW). It also occurs in the Hunter Valley and the eastern foothills of the Blue Mountains (Fig. 2). Naturalised occurrences in Victoria and South Australia have not been mapped.

Habitat: It grows on hills and slopes in eucalypt woodland, particularly in areas which have been recently burnt or subject to recent disturbance, e.g. roadworks. Soils are sandy or loamy.

Phenology: flowers and fruits may be found at any time of the year.

Conservation status: not of concern.

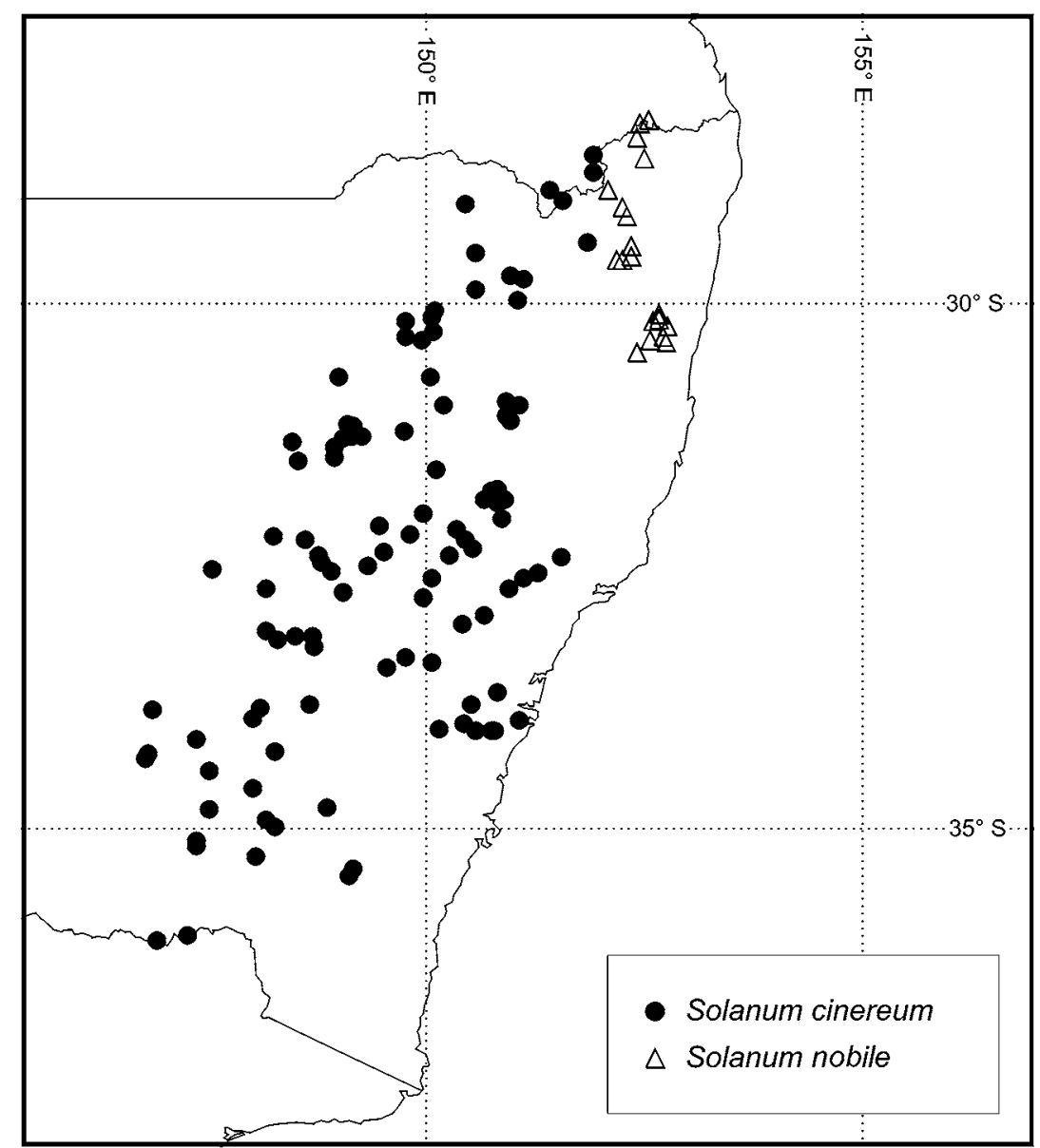

Fig. 2. Distribution of Solanum cinereum and S. nobile. 
Selected specimens (from 128 examined): Queensland: Darling Downs District: Severnlea, Morwood s.n., 5 May 1961 (BRI); 5.4 km E of Arcot, ENE of Texas, Bean 16651, 27 May 2000 (BRI, MEL, NSW); Glen Lyon-Mingoola area, near Stanthorpe, Taylor s.n., 4 Apr 1957 (BRI).

New South Wales: North Western Plains: Gulargambone, Ryan s.n., Jan 1912 (NSW67321). North west Slopes: 16 km WNW of Inverell, Henderson H2313, 23 Sep 1975 (BRI, NSW); Eulah Creek, c. 15 km E of Narrabri, Welch s.n., 13 Sep 1926 (NSW440668); near Little Sugarloaf Mtn, near Gunnedah, Johnson \& Constable s.n., 1 Nov 1954 (NSW31332); Timor Rock, W of Coonabarabran, Salasoo 2217, 4 Jan 1962 (NSW). Northern Tablelands: Deepwater, Boorman s.n., Jan 1911 (NSW67247); Killarney Gap, Nandewar Range, Salasoo 3961, 26 Aug 1970 (NSW). North Coast: Singleton-Gresford road, just before Branxton T/O, Powell 213 \& Seur, 30 Sep 1975 (NSW); Singleton-Bulga road at Wollombi T/O, Hartley 34, 7 Feb 1966 (BRI, NSW). Central Western Slopes: Kiernan's Ck, Kars Springs, 14 miles or 33 km SW of Murrurundi, Pickard \& Coveny 1238, 11 June 1969 (NSW); 4.4 km S of Mumbil, via Wellington, Bean 15813, 20 Nov 1999 (BRI, NSW); Weddin Mountain N.P., $15 \mathrm{~km} \mathrm{~W}$ of Grenfell, P.L.Wilson 841003, Oct 1984 (NSW). Central Tablelands: Bathurst to Sofala, Maiden \& Cambage s.n., Mar 1910 (NSW67243). Central Coast: Putty, just beyond P.O., Powell 189 \& Seur, 29 Sep 1975 (NSW); Marsden Park, Walker s.n., 17 Nov 1970 (NSW441463). South Western Slopes: Old Junee, Ridgway s.n., 3 Dec 1948 (NSW67303); Lake Albert, 8 miles [13 km] S of Wagga, Annison s.n., Mar 1911 (NSW67316); Cumberoona Reserve, Wymah, Mitsch s.n., 2 Mar 1951 (NSW67299). Southern Tablelands: 8 miles [13 km] from Queanbeyan on road to Cooma, Gibbs s.n., 23 Apr 1959 (NSW464758).

\section{Solanum nobile A.R.Bean sp. nov.}

affinis Solano cinereo sed ab eo statura multo minore, ramulo sparse armato, absentia aculeorum in pagina inferiore folii adulti, pilis stellatis minoribus atque dense aggregatis in pagina superiore folii, aculeis calycis absenti vel quam 5 paucioribus in quoque flore et germine glandulari differens.

Type: New South Wales: Northern Tablelands: Gwydir Highway, Gibraltar Range N.P., $0.7 \mathrm{~km}$ east of watershed, A.R. Bean 16850, 8 September 2000 (holo BRI; iso AD, K, MEL, NSW).

S. sp. Q5, T.D. Stanley \& E.M. Ross, Fl. South-eastern Qld 2: 424 (1986).

S. sp. (aff. cinereum), J.B. Williams, G.J. Harden \& W.J.F. McDonald, Trees \& shrubs in rainforest of NSW $\mathcal{E}$ southern Qld, p. 58 (1984).

Illustration: N. Nicholson \& H. Nicholson, Rainforest Plants IV, p. 64 (1994), as Solanum sp. aff. cinereum.

Shrub 1.5-4 m high. Fertile branchlets terete, white to grey, tomentose, with dense stellate hairs (stellae overlapping, but branchlet visible), sparsely armed with prickles (1-8 per dm of branchlet) each 3-7 mm long, glabrous; stellae all more or less sessile, c. $0.25 \mathrm{~mm}$ across, lateral rays $6-7$, central ray $0-1$ times as long as laterals. Juvenile leaves ovate in outline, $9-13 \times 5.5-8 \mathrm{~cm}$, deeply lobed, with $2-4$ pairs of acute lobes, prickly on both surfaces. Adult leaves ovate in outline, deeply lobed, lobes $2-4$ on each side, acute, lobing index 1.7-3.8; lamina 7-14 cm long, 3-5.2 cm wide, 1.4-2.7 times longer than broad, apex acute, basally dimidiate, oblique part 1-8 $\mathrm{mm}$ long, obliqueness index 1-6\%. Petioles $1.3-3.5 \mathrm{~cm}$ long, 17-26\% length of lamina, prickles often present. Upper leaf surface green, flat between major veins; prickles present on midvein and secondary veins; stellae sparse (cores $0.4-0.5 \mathrm{~mm}$ apart), distributed throughout lamina, $0.15-0.2 \mathrm{~mm}$ across, sessile, lateral rays 6-8, central ray $0-0.5$ times as long as laterals. Lower leaf surface white to pale yellow, prickles mostly absent or occasionally present (1-2), on midvein only; stellae densely packed in several layers, obscuring leaf surface, $0.35-0.45 \mathrm{~mm}$ across, mostly long-stalked (loose tomentum), lateral rays $6-7$, central ray $0-0.5$ times as long as laterals. Inflorescence pseudoracemose, axis present, 4-9-flowered, prickles absent or rarely 1-2 present on axis and pedicels; pedicels $10-17 \mathrm{~mm}$ long at anthesis. Calyx densely stellate-hairy, stellae 
0.4-0.7 $\mathrm{mm}$ across, transparent or purple, lateral rays $6-8$, central ray $1-1.5$ times as long as laterals, prickles absent or 1-5 per flower; hypanthium campanulate, 3-6 mm long at anthesis, lobes attenuate, $5-8 \mathrm{~mm}$ long at anthesis. Corolla rotate, purple, $21-33 \mathrm{~mm}$ across. Filaments 1-1.3 mm long, glabrous; anthers $4.5-5.5 \mathrm{~mm}$ long. Ovary surface with stipitate glands on the distal half; functional style 9-10 $\mathrm{mm}$ long, erect, with stipitate glands (and sometimes 1-2 stellae) on the proximal half, stellae with 7-9 lateral rays; stigma entire. Mature fruits 1-3 per inflorescence, globular or slightly oblate, pale green to yellow-green, $18-24 \mathrm{~mm}$ diameter, pericarp $0.8-1 \mathrm{~mm}$ thick when fresh, surface glabrous. Fruiting calyx not noticeably accresent. Pedicels 16-20 mm long in fruit. Seeds pale, $2.5-2.8 \mathrm{~mm}$ long. Fig. $3 \mathrm{a}-\mathrm{b}$.

Distribution: found from extreme southern Queensland (Killarney area) to the upper Bellingen valley, south of Dorrigo, N.S.W. (Fig. 2). There are also old records from 'Macleay River' (N.S.W.) and from Flying Fox Creek near Canungra (Qld).

Habitat: It is confined to rainforest margins or tall eucalypt forest with rainforest understorey, and currently known from between 700-1050 metres altitude. At the higher altitudes near Deervale, it grows in association with Nothofagus moorei (Antarctic Beech).

Phenology: flowers September-October; fruits maturing in January.

Notes: S. nobile has been confused with $S$. cinereum. It differs from S. cinereum by its greater stature, mostly unarmed adult-leaf lower surface, calyces unarmed or with a few prickles only, ovary with stipitate glands, pale seeds, and the rainforest habitat.

It is also closely related to $S$. curvicuspe with which it shares the deeply and acutelylobed juvenile leaves, and the preferred habitat. S. nobile differs by the deeply lobed adult leaves, the sparse indumentum on the upper leaf surface, loose indumentum of lower leaf surface and the larger calyx-stellae with longer central rays. S. nobile occurs to the north of $S$. curvicuspe, and there is no evidence of intergradation between the species.

Conservation status: Applying the criteria of the IUCN (Anon. 1994), a category of 'Vulnerable' is proposed (Criteria B1, B3(d), C1 and C2(a)). In the early 1900s, several collections were made from relatively low altitudes. No populations can now be found at these localities, which could indicate that they have been unable to compete with the pernicious weed Lantana camara, and hence driven to extinction. However several populations persist at altitudes beyond the climatic tolerance of Lantana. It is conserved in Gibraltar Range National Park, and may be present in other conservation reserves.

Etymology: The epithet is from the Latin nobilis, meaning noble or grand. This is a reference to the plant's tall stature, and its impressive floral display.

Selected specimens (from 27 examined): Queensland: Moreton District: Flying Fox Creek, Shirley s.n., undated (BRI). Darling Downs District: Main Range, c. 24 km ENE of Killarney, Everist 8124, 13 Oct 1968 (BRI, NSW); The Head, east of Killarney, Bird s.n., 12 Sep 1982 (BRI).

New South Wales: North Coast: top of Tooloom Range, near Acacia Creek, Dunn s.n., Sep 1908 (NSW67315); Chapman's Plain Nature Reserve, Clouds Creek SF, $21.5 \mathrm{~km} \mathrm{~N}$ of Dorrigo, Cameron 6721, 8 Sep 1976 (MEL); 2.4 km NNE of Billy's Ck, Ebor to Nymboida, Haegi 1413, Sep 1977 (NSW); $13.1 \mathrm{~km}$ along Moses Rock road from Cascade, NNE of Dorrigo, Bean 16873, 10 Sep 2000 (BRI, CANB, NE, NSW); Black Scrub, Upper Bellinger valley, Symon 11527, 17 Jan 1979 (AD, BRI, NSW); Macleay River, collector unknown, undated (NSW67313). Northern Tablelands: Surface Hill, ESE of Tenterfield, Moriarty s.n., Jan 1975 (NSW); Gibraltar Range N.P., c. 67 km E of Glen Innes, Coveny 2237, 3 Oct 1969 (NSW); 1.5 km W of Heffron's Lookout, Gwydir Highway, Conn 3664 E Brown, Oct 1992 (NSW); Deervale, 90 km ENE of Armidale, Coveny 5679 \& Lander, 2 Oct 1974 (NSW). 


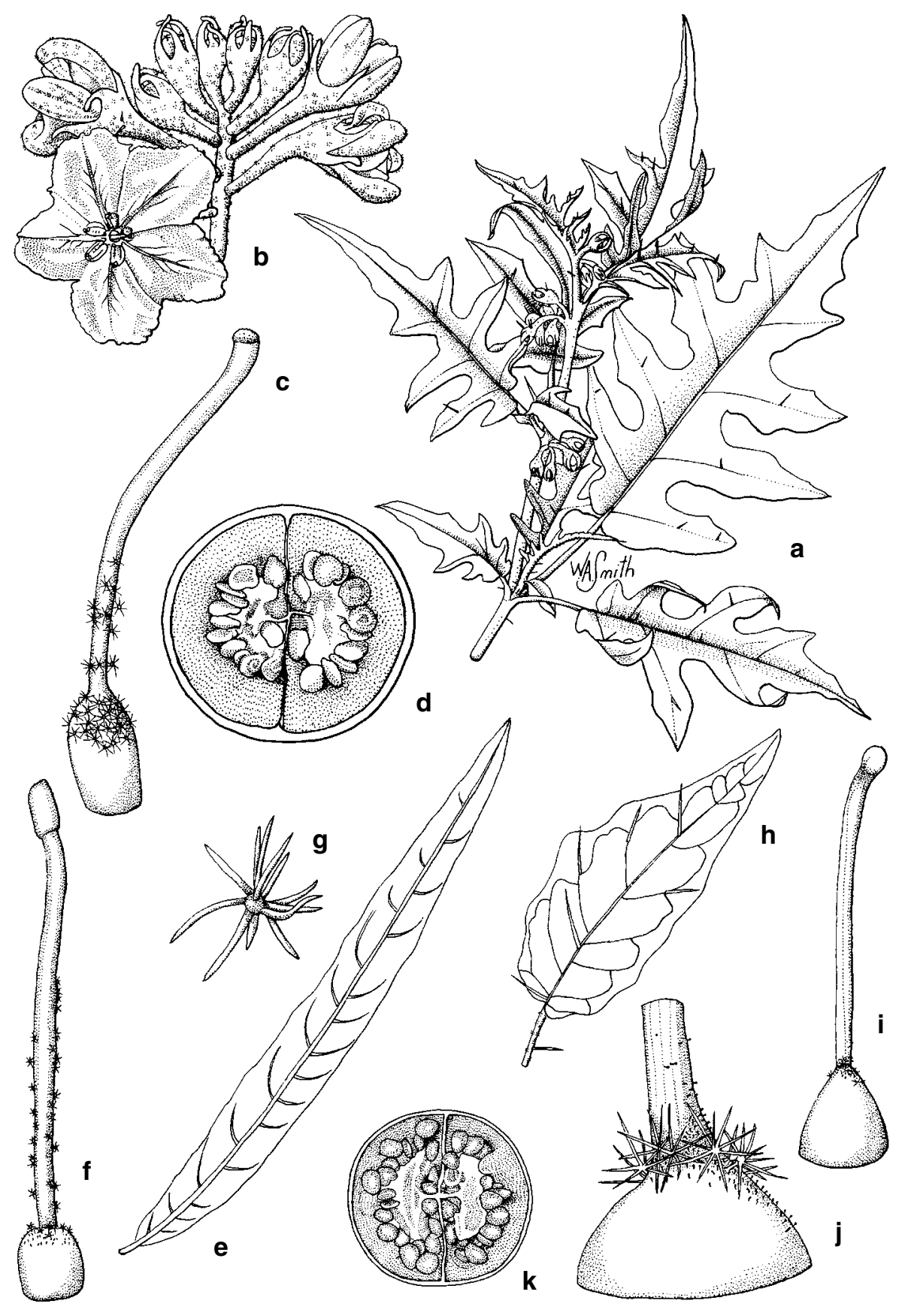

Fig. 3. Solanum nobile. $\mathbf{a}$, flowering branchlet $\times 0.48 ; \mathbf{b}$, inflorescence $\times 0.95$. Solanum brownii; $\mathbf{c}$, ovary and style $\times 5.7 ; \mathbf{d}$, transverse section of mature fruit $\times 1.4$. Solanum limitare; $\mathbf{e}$, adult leaf $\times 1 ; \mathbf{f}$, ovary and style $\times 5.7 ; \mathbf{g}$, a stellate hair from the style $\times 57$. Solanum silvestre. $\mathbf{h}$, adult leaf $\times 0.95 ; \mathbf{i}$, ovary and style $\times 5.7 ; \mathbf{j}$, junction of ovary and style showing stipitate glands and stellate hairs $\times 19$; k, transverse section of mature fruit $\times 1$.4. (a, from Bean 16850; b, from Bean 16873; c, from Smithers s.n.; d, from Bean 17209; e,f,g, from Bean 16080; h,i, j, from Constable 4436; k, from Bean 17196.) 
3. Solanum curvicuspe Domin, Repert. Spec. Nov. Regni Veg. 12: 131 (1913). Type: New South Wales. Hastings River, C. Moore s.n., 1865-6 (lecto K, here chosen; probable isolecto MEL).

S. curvicuspe f. curvispina Domin, Repert. Spec. Nov. Regni Veg. 12: 131 (1913). Type: Clarence River, H. Beckler (holo K).

Shrub 1.5-3 m high. Fertile branchlets terete, grey, tomentose, with very dense stellate hairs (stellae obscuring branchlet), sparsely armed with prickles (0-5 per $\mathrm{dm}$ of branchlet) each 5-8 mm long, glabrous; stellae all more or less sessile, $0.2-0.3 \mathrm{~mm}$ across, lateral rays $6-8$, central ray $0-0.5$ times as long as laterals. Juvenile leaves ovate in outline, $10-14 \times 6-8 \mathrm{~cm}$, deeply lobed, with 2-4 pairs of acute lobes, prickly on both surfaces. Adult leaves lanceolate to elliptical, entire or slightly lobed, lobes 2-3 on each side, obtuse, lobing index 1-1.2; lamina 7-13.5 cm long, $1.7-3.7 \mathrm{~cm}$ wide, 3.7-4.8 times longer than broad, apex obtuse or acute, basally dimidiate or symmetrical, oblique part 0-2.5 mm long, obliqueness index 0-4\%. Petioles 1-1.7 cm long, 12-16\% length of lamina, prickles rarely present. Upper leaf surface grey-green, flat between major veins; prickles absent, or present on midvein only; stellae dense (cores c. $0.1 \mathrm{~mm}$ apart), distributed throughout lamina, $0.15-0.2 \mathrm{~mm}$ across, sessile, lateral rays $7-8$, central ray 0-0.5 times as long as laterals. Lower leaf surface white to pale yellow, prickles absent; stellae densely packed in several layers, obscuring leaf surface, $0.25-0.35 \mathrm{~mm}$ across, more or less sessile (close tomentum), lateral rays $7-8$, central ray $0-0.5$ times as long as laterals. Inflorescence pseudo-racemose, axis present, 3-9-flowered, prickles absent; pedicels 7-11 mm long at anthesis. Calyx densely stellate-hairy, stellae $0.3-0.4 \mathrm{~mm}$ across, transparent or purple, lateral rays $7-8$, central ray $0-0.5$ times as long as laterals, prickles absent; hypanthium campanulate, 2-4 $\mathrm{mm}$ long at anthesis, lobes attenuate, $3.5-5.5 \mathrm{~mm}$ long at anthesis. Corolla rotate, purple, $20-25 \mathrm{~mm}$ across. Filaments c. $1.5 \mathrm{~mm}$ long, glabrous; anthers $4.5-5.0 \mathrm{~mm}$ long. Ovary surface with stipitate glands on the distal half; functional style $9-9.5 \mathrm{~mm}$ long, erect, glabrous or with stipitate glands on the proximal half; stigma entire. Mature fruits 1-4 per inflorescence, globular to oblate, pale green, $17-22 \mathrm{~mm}$ diameter, pericarp $0.8-1 \mathrm{~mm}$ thick when fresh, surface glabrous. Fruiting calyx not noticeably accresent. Pedicels 15-20 mm long in fruit. Seeds white to pale yellow, 2.1-2.4 mm long.

Distribution: occurs on the coastal ranges from Kempsey to Gloucester, N.S.W. (Fig. 4).

Habitat: it grows in disturbed sites in notophyll rainforest or wet eucalypt forest with rainforest understorey.

Phenology: flowers from August-October; fruits maturing November-January.

Typification: Three of the four collections cited by Domin in the protologue have been seen by the author. The Hastings River collection has been chosen as the lectotype, as it is a good quality specimen which matches the protologue very well.

Notes: closely related to $S$. limitare, but differs by the dense overlapping stellae on the leaf upper surface, only $0.15-0.2 \mathrm{~mm}$ across; styles glabrous or with a few stipitate glands, the attenuate calyx lobes, and the acutely lobed juvenile leaves. It is also close to $S$. nobile (see notes under that species).

S. curvicuspe f. curvispina is a minor variant that clearly falls within the morphological range for $S$. curvicuspe. However the reputed locality 'Clarence River' is outside the known range of $S$. curvicuspe.

Conservation status: Applying the criteria of the IUCN (Anon. 1994), a category of 'Vulnerable' is proposed (Criteria A2(e), B2(d,e) and B3(d)). At least some populations are threatened by Lantana camara, which occupies the same habitat. 
Selected specimens (from 18 examined): New South Wales: North Coast: Spokes Trail, c. 5 km N of Spokes Mtn, Whaite 4452 \& Whaite, 1 Aug 1982 (BRI, NSW); Forbes Forest road, NW of Wauchope, Bean 15704, 8 Nov 1999 (BRI, NSW); Bellangry S.F., NW of Wauchope, Bean 17225, 29 Dec 2000 (BRI, MEL, NE, NSW); 87 km W of Wauchope, Lamb s.n., 9 Sep 1979 (NSW374428); Ten Mile Hill, Oxley Hwy, W of Yarras, Davis 15 \& 18, 6 Oct 1941 (NSW); Doyles River SF, 30 miles [48 km] NW of Taree, Constable 6323, 16 Nov 1965 (NSW).

4. Solanum brownii Dunal, Hist. Nat. Solanum 201 (1813)

Solanum violaceum R.Br., Prodr. 445 (1810), nom. illeg., non Ortega (1797).

Type: New South Wales: "Paterson's River, Oct 1804", R. Brown [Bennett No. 2671] (lecto BM; isolecto K), fide Symon (1981).

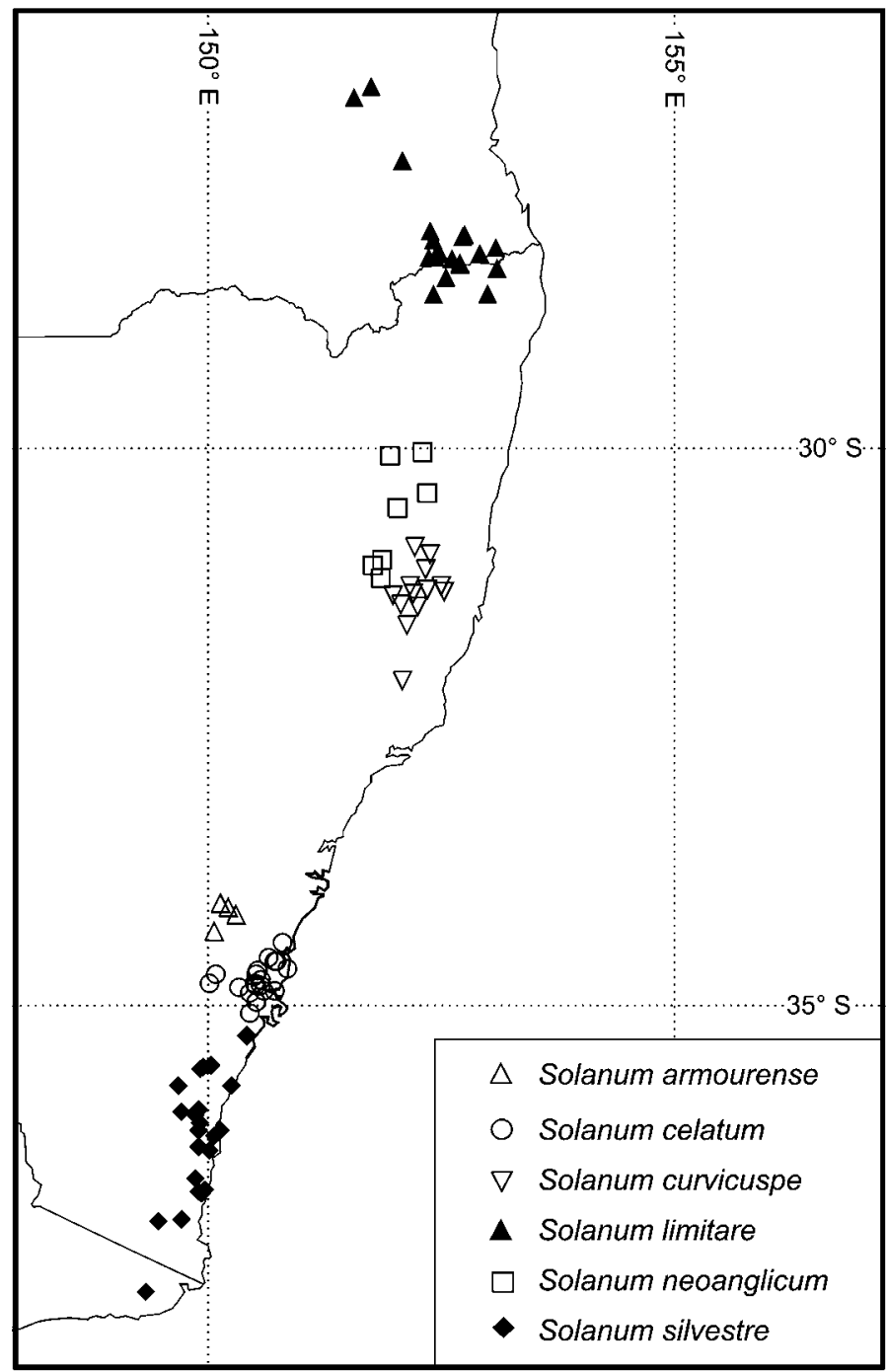

Fig. 4. Distribution of Solanum armourense, S. celatum, S. curvicuspe, S. limitare, S. neoanglicum and S. silvestre. 
S. elegans Dunal in Poir., Encycl., Suppl. 3: 769 (1814).

Type: $t .58$ of unpublished illustrations (icono MPU, fide Symon (1981) n.v., photo AD!).

Solanum violaceum var. album Maiden \& Betche, Proc. Linn. Soc. New South Wales 29: 747 (1904). Types: Mt Dangar, Gungal, J.L. Boorman, September 1904 (syn NSW); Wallsend, J.L. Boorman, September 1904 (syn NSW).

Shrub 0.6-1.8 m high. Fertile branchlets terete, grey, tomentose, with very dense (hairs obscuring branchlet) stellate hairs, sparsely armed with prickles (0-12 per $\mathrm{dm}$ of branchlet) each 3-9 mm long, glabrous; stellae sessile to shortly stipitate, $0.2-0.4 \mathrm{~mm}$ across, lateral rays $6-8$, central ray $0-0.5$ times as long as laterals. Juvenile leaves elliptical in outline, c. $10 \times 3 \mathrm{~cm}$, shallowly to deeply lobed with 2-3 pairs of obtuse lobes, prickly on both surfaces or on upper surface only. Adult leaves lanceolate, entire to repand, lobes $1-3$ on each side, obtuse, lobing index 1-1.2; lamina $6.5-13 \mathrm{~cm}$ long, 1.4-2.9 $\mathrm{cm}$ wide, 3.5-9 times longer than broad, apex acute, basally dimidiate or symmetrical, oblique part $0-4 \mathrm{~mm}$ long, obliqueness index $0-2 \%$. Petioles $0.7-1.5 \mathrm{~cm}$ long, 10-11\% length of lamina, prickles absent or rarely present. Upper leaf surface green to grey-green, bullate or wrinkled between major veins; prickles absent, or present on midvein only; stellae sparse (cores $0.3-0.5 \mathrm{~mm}$ apart), distributed throughout lamina, $0.15-0.25 \mathrm{~mm}$ across, sessile to shortly-stalked, transparent, lateral rays $6-8$, central ray 1-2 times as long as laterals. Lower leaf surface yellowish-white to rusty, prickles absent; stellae densely packed in several layers, obscuring leaf surface, $0.3-0.6 \mathrm{~mm}$ across, on stalks $0.3-0.4 \mathrm{~mm}$ long (loose tomentum), lateral rays 6-8, central ray 0.5-1.5 times as long as laterals. Inflorescence pseudo-umbellate when young, later pseudo-racemose, 5-8-flowered, prickles absent from rachis and pedicels; pedicels 13-18 mm long at anthesis. Calyx outer surface densely stellate-hairy, stellae $0.4-0.5 \mathrm{~mm}$ across, transparent or purple, lateral rays $7-8$, central ray $0.5-1.5$ times as long as laterals. Prickles absent or 1-5 per flower, scattered; hypanthium campanulate, 4-5.5 $\mathrm{mm}$ long at anthesis; lobes deltate to attenuate, $2.5-5 \mathrm{~mm}$ long at anthesis. Corolla rotate to shallowly lobed, purple or rarely white, 22-32 $\mathrm{mm}$ across. Filaments 1-1.5 mm long, glabrous; anthers 5-6 mm long. Ovary surface with stipitate glands and few to many stellate hairs on the distal half; functional style $8.5-10 \mathrm{~mm}$ long, erect, with stipitate glands and some stellate hairs on the proximal half, stellae with 10-15 lateral rays; stigma entire. Mature fruits 1-3 per inflorescence, globular, pale green to yellow-green, 18-29 mm diameter, pericarp $0.8-1.2 \mathrm{~mm}$ thick when fresh, surface glabrous. Fruiting calyx not noticeably accresent. Pedicels $12-18 \mathrm{~mm}$ long in fruit. Seeds white to pale yellow, 2.7-3.0 mm long. Fig. 3. c-d.

Distribution: $S$. brownii has a relatively restricted distribution centred on the Hunter Valley, N.S.W. It extends north-west as far as Coonabarabran, south to the Blue Mountains, and approaches the coast around Dungog and Gloucester (Fig. 5). It can be common in places.

Habitat: It grows in eucalypt woodland with a dense shrubby understorey, on hillsides, particularly in places where the soil has been disturbed. Soils are loamy or sandy.

Phenology: flowers June-October; fruits maturing November-January.

Typification: Brown's 'Paterson's River' is today the Hunter River. It is not known just where Brown collected the type, but his furthest upstream was between Maitland and Branxton, where he climbed Mt Hudson (Vallance 1990). Since S. brownii is generally a hillside (rather than riverine) plant, he perhaps collected it there.

The type specimen of S. elegans is apparently lost. Bentham (1868: 461) inferred that he did not see any authentic material. D. Symon searched unsuccessfully at P and MPU for a type specimen, and subsequently (Symon 1981) he selected an iconotype for S. elegans. 
Notes: I regard the iconotype to be an accurate representation of the plant Dunal describes in the protologue of S. elegans. Both S. brownii and S. elegans are described by Dunal as having a 'wrinkled' upper leaf surface, a feature more obvious in S. brownii than any other species of the group.

The S. elegans iconotype resembles the type of S. brownii in many ways, but the leaves are somewhat broader and slightly sinuate, the stems and leaves are rather more prickly, and there are a few prickles on the calyx of some flowers. In many Solanum species, juvenile plants have broader and more-lobed leaves than more mature plants, and are generally more prickly on all parts. Hence I believe that the specimen forming the type of S. elegans was taken from a young, vigorously growing plant of S. brownii, and that the two are synonymous.

The early collection of the S. elegans type lends further support to this conclusion. The specimen on which Dunal based S. elegans was present in the Paris herbarium in 1814, so that it must have been collected prior to 1813. Botanical exploration in eastern Australia at that time was in its infancy. The specimen must have come from the greater Sydney area (perhaps even collected by Robert Brown). It could not have come from the areas west of the Great Dividing Range where other related taxa occur. See further discussion below under the treatment of S. amblymerum Dunal.

Some specimens from the Gosford-Wyong area, while included here under S. brownii, are atypical because of their attenuate calyx lobes and close tomentum on the leaf undersides.

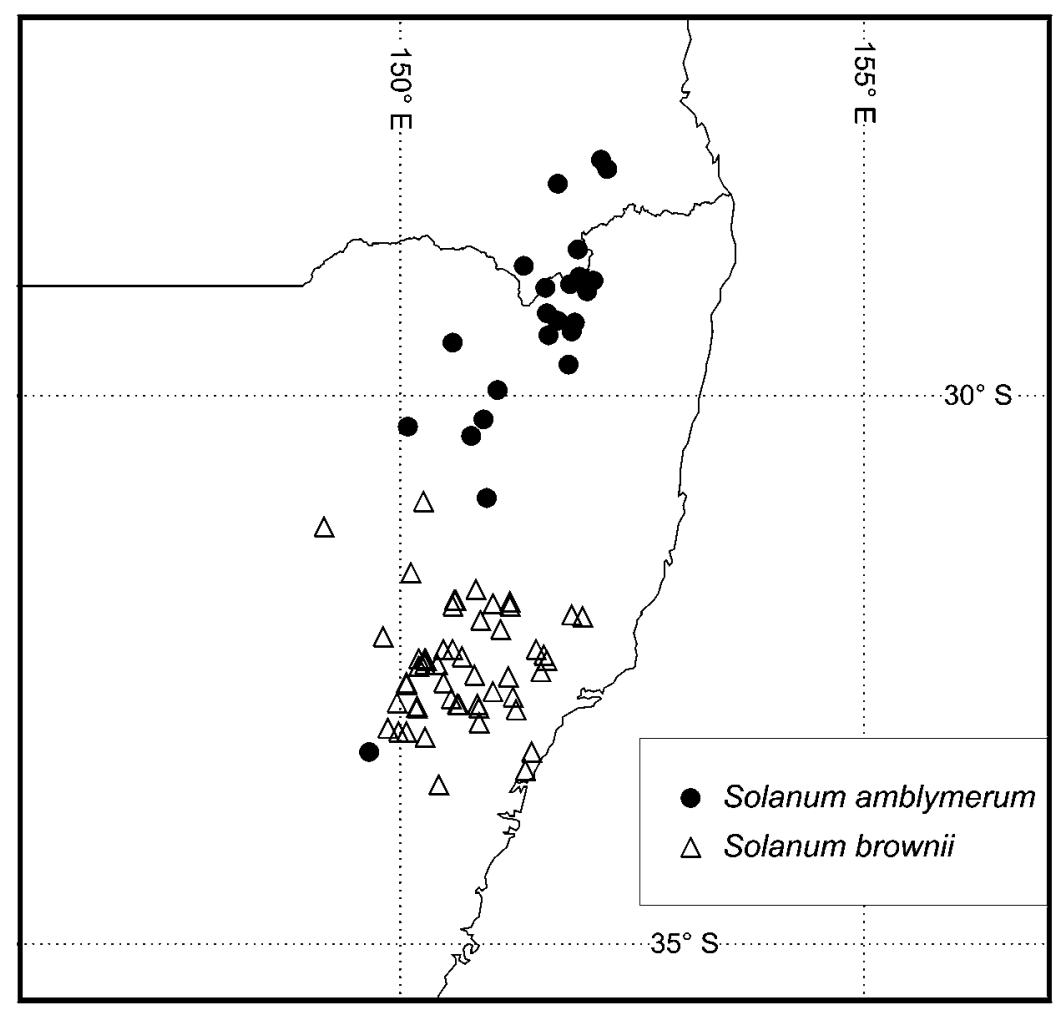

Fig. 5. Distribution of Solanum amblymerum and S. brownii. 
Specimens from the Rylstone and Upper Cudgegong areas (often on sandstone slopes) have leaves that are unusually narrow and with a very dense tomentum. The calyx lobes are deltate and often purple. However, they have been included here under S. brownii because numerous intermediate specimens exist.

Conservation status: not of concern.

Selected specimens (from 65 examined): New South Wales: North Western Slopes: Gunnedah, Boorman s.n., Sep 1908 (NSW59777); Baradine Rd, 8 miles [13 km] from Coonabarabran, Althofer 14, Sep 1951 (MEL). Northern Tablelands: Bald Rock, Liverpool Range, Johnson \& Constable s.n., 31 Oct 1954 (NSW30197). Central Western Slopes: $5 \mathrm{~km} \mathrm{~W}$ of Moonan Flat, along road to Scone, Greuter 20598, 8 Sep 1988 (NSW); 24.1 km from Rylstone towards Bylong, Bean 17209, 28 Dec 2000 (BRI, MEL, NSW); Sandy Hollow, Goulburn River valley, Tame 433, Sep 1979 (NSW); Apex Lookout, $2.8 \mathrm{~km} \mathrm{~W}$ of Denman, Bishop 630 et al., 14 Nov 1984 (NSW); E slope of Mt Dangar, Gungal, Rodd 339, 27 Aug 1966 (NSW); Honeysuckle Creek, Murrumbo-Kerrabee, Johnson s.n., 19 Sep 1951 (NSW438466); Baerami Ck, 28 miles [45 km] SW of Muswellbrook, Story 6740, 6 Oct 1959 (NSW). North Coast: Mt Richardson, on road from Dungog to Gresford, Swan 18, June 1974 (BRI); Paterson River, Boorman s.n., Aug 1906 (NSW59775); Milbrodale, Singleton-Howes Valley road, Constable s.n., 29 Aug 1957 (NSW42387). Central Tablelands: $5 \mathrm{~km}$ E of Olinda on Mt Coricudgy road, Chapman 1513, 1 Oct 1979 (NSW); Glen Davis track, 2 km SSW of Glen Davis P.O., Rimes 65 et al., 2 Dec 1987 (NSW); Genowlan Mtn, 7 miles [11 km] NE of Capertee, Constable 5029, 23 Sep 1964 (NSW); Tomah, Blue Mountains, Woolls s.n., undated (MEL). Central Coast: Gosford, Deane s.n., Oct 1888 (NSW67318).

5. Solanum amblymerum Dunal in A.DC., Prodr. 13: 294 (1852); S. violaceum var. amblymerum (Dunal) Maiden \& Betche, Census N.S.W. Pl. 181 (1916).

Type: New South Wales: Macquarie River, October 1822, A. Cunningham 90 (holo G-DC n.v., microfiche 13/1: 294.692; iso K, NSW).

\section{[S. elegans sensu Symon, non Dunal]}

Shrub 0.8-1.6 m high. Fertile branchlets terete, grey, tomentose, with very dense (hairs obscuring branchlet) stellate hairs, sparsely armed with prickles (1-11 per dm of branchlet) each 5-8 mm long, glabrous; stellae sessile to shortly stipitate, $0.35-0.4 \mathrm{~mm}$ across, lateral rays $7-10$, central ray $0-0.5$ times as long as laterals. Juvenile leaves lanceolate in outline, with 1-2 pairs of shallow or deep obtuse lobes, $7-10 \times 1.5-2.5 \mathrm{~cm}$, prickles present on upper and lower surface. Adult leaves linear to lanceolate, entire or with a single basal pair of obtuse lobes, lobing index 1-1.3; lamina 4.8-11 cm long, $0.5-1.3 \mathrm{~cm}$ wide, $6-13$ times longer than broad, apex obtuse or acute, basally dimidiate or symmetrical, oblique part $0-1.5 \mathrm{~mm}$ long, obliqueness index $0-2 \%$. Petioles $0.3-0.9 \mathrm{~cm}$ long, 5-14\% length of lamina, prickles rarely present. Upper leaf surface green, flat or wrinkled between major veins; prickles present on midvein only; stellae sparse (cores 0.4-0.7 $\mathrm{mm}$ apart), distributed throughout lamina, $0.1-0.2 \mathrm{~mm}$ across, sessile, lateral rays $7-8$, central ray $0-0.5$ times as long as laterals. Lower leaf surface white or yellowish, prickles often present on midrib; stellae very dense (obscuring leaf surface), $0.2-0.45$ $\mathrm{mm}$ across, more or less sessile (close tomentum), lateral rays $7-8$, central ray $0.5-1$ times as long as laterals. Inflorescence pseudo-racemose, axis present, 3-6-flowered, prickles absent from rachis and pedicels; pedicels $5-10 \mathrm{~mm}$ long at anthesis. Calyx densely stellate-hairy, stellae $0.25-0.4 \mathrm{~mm}$ across, transparent or purple, lateral rays 7-8, central ray 0.5-1 times as long as laterals, prickles absent. Hypanthium campanulate, 2-2.5 mm long at anthesis; lobes deltate or attenuate, 3.5-4.5 $\mathrm{mm}$ long at anthesis. Corolla rotate, purple, $24-28 \mathrm{~mm}$ across. Filaments $1.2-1.8 \mathrm{~mm}$ long, glabrous; anthers 5.5-6.5 mm long. Ovary surface with stipitate glands on the distal half, stellate hairs absent; functional style 10-11 mm long, erect, with sparse stipitate glands and stellate hairs on the proximal half, stellae with 9-10 lateral rays; stigma lobed or entire. Mature fruits 1-3 per inflorescence, globose to oblate, pale green, 11-16 $\mathrm{mm}$ diameter, pericarp $0.7-0.8 \mathrm{~mm}$ thick when fresh, surface glabrous. 
Fruiting calyx not noticeably accresent. Pedicels $10-13 \mathrm{~mm}$ long in fruit. Seeds white to pale yellow, 2.4-2.8 $\mathrm{mm}$ long.

Notes: S. amblymerum was placed in synonymy with S. elegans by Symon (1981). However neither the iconotype chosen by Symon nor the protologue of S. elegans are in accordance with the taxon named S. amblymerum. Furthermore, the type of S. elegans was collected prior to 1813, when the area of occurrence of S. amblymerum was unexplored.

Symon (loc. cit.) allied S. amblymerum (under the name S. elegans) with S. parvifolium, presumably because he thought they both have red fruits. Field studies have shown that the mature fruit colour for amblymerum is greenish-white, and its affinities are clearly with S. brownii. It differs from S. brownii by the frequent presence of prickles on the undersides of the adult leaves, as well as the narrower leaves with close tomentum, smaller fruits and shorter hypanthia. It is also close to S. limitare (see notes under that species).

The type of S. amblymerum was collected in October 1822. At that time, Cunningham was collecting in the vicinity of Bathurst (Field 1825), which lies on the Macquarie River. It has been collected only once from the Bathurst area since the type collection.

Distribution: extends from near Warwick in Queensland to around Barraba in New South Wales, with a single collection from near Bathurst in 1955 (Fig. 5).

Habitat: grows in shrubby eucalypt woodland, or eucalypt-Callitris woodland, on hills and slopes. It usually appears on recently burnt or disturbed sites. Soils are sandy.

Phenology: flowers recorded from June to January, with a peak between September and November. Fruits maturing from December-March.

Conservation status: not of concern.

Selected specimens (from 51 examined): Queensland: Darling Downs District: SF 595, near Mt Gammie North, Forster 11723, 27 Sep 1992 (BRI); 3 miles [5 km] N of Dalveen, Rothwell s.n., 10 July 1963 (BRI); Mt Janet road, Passchendaele S.F., NW of Stanthorpe, Bean 12471, 4 Oct 1997 (BRI); Sundown N.P., near Red Rock Gorge, Forster PIF12677 \& Halford, 8 Jan 1993 (AD, BRI). Moreton district: SW of Mt Hennessy, 'Glenrock', Grimshaw PG2694, 18 Mar 1997 (BRI).

New South Wales: Northern Tablelands: Jennings, Maiden \& Boorman s.n., Dec 1903 (NSW439373); Bonshaw-Glen Innes road, $5.5 \mathrm{~km}$ from Bruxner Hwy, Bean 17112, 16 Dec 2000 (BRI, NSW); Deepwater, Boorman s.n., Jan 1911 (NSW66607); $28 \mathrm{~km}$ SW of Bundarra on road to Barraba, Forster PIF14227 \& Machin, 7 Nov 1993 (BRI); Green Camp, Mt Kaputar NP, Coveny 8745 \& Roy, 18 Nov 1976 (NSW). North-western Slopes: 20 km NW of Torrington, Quirico 51 et al., 13 Oct 1990 (NSW); Howell, Maiden E Boorman s.n., Aug 1905 (NSW59700); $60 \mathrm{~km}$ by road E of Bonshaw towards Tenterfield, Coveny 6666 \& Hind, 24 Aug 1975 (NSW). Central Tablelands: Cheshire Creek, Wiagdon, Constable s.n., 17 Mar 1955 (NSW31330).

\section{Solanum limitare A.R. Bean sp. nov.}

affinis Solano amblymero sed pedicellis sub anthesi necnon in fructu longioribus, stellis in pagina superiore folii majoribus, antheris brevioribus, germine glandulis stipitatis necnon pilis stellatis instructo et stellis in stylo radiis lateralibus 13-20 (non 9-10) praeditis differens.

Type: Queensland: Moreton district: adjacent to Mt Binga S.F., $11 \mathrm{~km} \mathrm{SE}$ of Cooyar, A.R. Bean 16080, 21 February 2000 (holo BRI; iso MEL, NSW).

Shrub 0.3-0.8 m high. Fertile branchlets terete, rusty to grey, tomentose, with very dense stellate hairs (stellae obscuring branchlet), sparsely armed with prickles (1-6 per $\mathrm{dm}$ of branchlet) each 3-6 mm long, glabrous; stellae all more or less sessile, $0.25-0.4 \mathrm{~mm}$ across, lateral rays $6-8$, central ray $0-0.5$ times as long as laterals. Juvenile leaves 
lanceolate to ovate in outline, with 1-2 pairs of shallow obtuse lobes (or unlobed), $6.5-10 \times 2-3.5 \mathrm{~cm}$, prickles present on upper and lower surfaces. Adult leaves lanceolate, entire; lamina 7-10.5 cm long, 0.9-1.7 cm wide, 4.7-8.5 times longer than broad, apex acute, basally dimidiate, oblique part 1-3.5 mm long, obliqueness index 1-4\%. Petioles $0.5-0.8 \mathrm{~cm}$ long, 6-9\% length of lamina, prickles rarely present. Upper leaf surface grey-green, flat between major veins; prickles present on midvein only; stellae sparse to moderate (cores $0.2-0.6 \mathrm{~mm}$ apart), distributed throughout lamina, 0.2-0.4 $\mathrm{mm}$ across, sessile, lateral rays $6-8$, central ray $0-0.5$ times as long as laterals. Lower leaf surface white to pale yellow, prickles rarely present; stellae densely packed in several layers, obscuring leaf surface, $0.35-0.45 \mathrm{~mm}$ across, more or less sessile (close tomentum), lateral rays $7-8$, central ray $0.5-1$ times as long as laterals. Inflorescence pseudo-racemose, axis present, 3-6-flowered, prickles absent; pedicels 11-20 mm long at anthesis. Calyx densely stellate-hairy, stellae $0.3-0.45 \mathrm{~mm}$ across, transparent, lateral rays $7-8$, central ray $0.5-1$ times as long as laterals, prickles absent; hypanthium campanulate, $2.5-4 \mathrm{~mm}$ long at anthesis, lobes deltate to rostrate, 3-5 $\mathrm{mm}$ long at anthesis. Corolla rotate, purple, $19-31 \mathrm{~mm}$ across. Filaments $0.7-1.5 \mathrm{~mm}$ long, glabrous; anthers 3.5-5.5 mm long. Ovary surface with stipitate glands and stellate hairs on the distal half; functional style 10-12 mm long, erect, with stellate hairs on the proximal half, stellae with 13-20 lateral rays; stigma entire. Mature fruits 1-3 per inflorescence, globular, pale green, $14-17 \mathrm{~mm}$ diameter, pericarp c. $0.5 \mathrm{~mm}$ thick when fresh, surface glabrous. Fruiting calyx not noticeably accresent. Pedicels $16-20 \mathrm{~mm}$ long in fruit. Seeds white to pale yellow, 2.7-2.9 mm long. Fig. 3 e-g.

Distribution: extends from the Bunya Mountains (Queensland) to Kyogle and Urbenville in New South Wales, with numerous records from the 'Scenic Rim', between Lamington N.P. and Mt Cordeaux (Fig. 4).

Habitat: grows in grassy eucalypt woodland, often within a few hundred metres of a rainforest edge.

Phenology: flowers mostly September-February; fruits maturing January-August.

Notes: S. limitare is closely related to $S$. amblymerum, differing by the longer pedicels both at anthesis and in fruit, the strongly attenuate calyx-lobes (deltate for amblymerum), the larger stellae of upper leaf surface, the shorter anthers, the ovary bearing both stipitate glands and stellate hairs, and stellae on the style with 13-20 lateral rays.

This species apparently does not exceed $80 \mathrm{~cm}$ in height, and may sprout annually from rhizomes.

Conservation status: Applying the criteria of the IUCN (Anon. 1994), a category of 'Vulnerable' is proposed (Criteria A1(c), B1 and B3(d)). Most of the remaining populations are under direct threat from Lantana camara, which out-competes it.

Etymology: The specific epithet is from the Latin limes, limitis meaning 'a border or boundary'. This refers to the occurrence of this species on both sides of (and at times right on) the Queensland-New South Wales border.

Selected specimens (from 34 examined): Queensland: Burnett District: Long Plain, Bunya Mtns, Fairfax 60, 1995 (BRI); Kumbia, N.Michael s.n., 30 Oct 1947 (BRI). Darling Downs: near summit of Mt Cordeaux, L.S. Smith s.n., 25 Apr 1969 (BRI); Wilsons Peak, Maiden s.n., Dec 1907 (NSW72084). Moreton District: Ben Lomond Peak, Bird s.n., 9 Jan 1988 (BRI); between Spring Bluff and Murphy's Creek, White 7017, 2 Aug 1930 (BRI); Croftby road, near Boonah Border Gate, Forster 6210, 27 Jan 1990 (BRI); Lamington N.P., O'Reilley 211, 21 Jan 1992 (BRI).

New South Wales: North Coast: Levers Plateau, Swan 64, 9 July 1974 (BRI); Mt Lindesay, 7 miles [11 km] ENE of Woodenbong, Coveny 4562 \& Rodd, 9 Sep 1972 (NSW); North Obelisk, 1 mile [1.6 km] WSW of Urbenville, Constable 6646, 2 Dec 1965 (NSW); E of Mt Boorabee, near Kyogle, Salasoo 2583, 2 Jan 1963 (NSW). 


\section{Solanum silvestre $A$.R. Bean sp. nov.}

affinis Solano brownii, ab eo fructibus multo minoribus pericarpio tenuiore, folii pagina inferiore tomento coarctato pilorum stellatorum 0.2-0.3 mm diam. (non 0.3-0.6 mm diam.) instructa, stylis brevioribus et foliis latioribus 2.5-3.5-plo longioribus quam latioribus (adversum 3.5-9-plo) differens.

Type: New South Wales: South Coast: Box Cutting Rd, Bodalla S.F., S of Bodalla, A.R.Bean 17196, 25 December 2000 (holo BRI; iso CANB, K, MEL, NSW, NY).

Shrub to 1-1.8 $\mathrm{m}$ high. Fertile branchlets terete, grey or brown, tomentose, with very dense (hairs obscuring branchlet) stellate hairs, sparsely armed with prickles (0-11 per $\mathrm{dm}$ of branchlet) each 5-8 $\mathrm{mm}$ long, glabrous; stellae sessile to shortly stipitate, $0.25-0.3 \mathrm{~mm}$ across, lateral rays $7-8$, central ray $0-0.5$ times as long as laterals. Juvenile leaves shallowly lobed, ovate to broadly ovate, $6.5-14 \times 4.5-9 \mathrm{~cm}$, prickly on both surfaces or on upper surface only. Adult leaves elliptical in outline, entire or sinuate, lobes $0-3$ on each side, obtuse, lobing index 1-1.4; lamina 5-10 cm long, 2.0-3.6 cm wide, 2.5-3.4 times longer than broad, apex acute, basally dimidiate or symmetrical, oblique part 0-3 mm long, obliqueness index 0-4\%. Petioles $0.9-2.2 \mathrm{~cm}$ long, $18-28 \%$ length of lamina, prickles often present. Upper leaf surface green, flat between major veins; prickles present on midvein only, or also on secondary veins; stellae sparse (cores $0.3-0.5 \mathrm{~mm}$ apart), distributed throughout lamina, $0.15-0.25 \mathrm{~mm}$ across, sessile, lateral rays 6-8, central ray $0.5-2$ times as long as laterals. Lower leaf surface yellow to white, prickles rarely present; stellae densely packed in several layers, obscuring leaf surface, $0.2-0.3 \mathrm{~mm}$ across, more or less sessile (close tomentum), lateral rays 7-8, central ray 0-0.5 times as long as laterals. Inflorescence pseudo-racemose, axis present, 3-6-flowered, prickles absent from rachis and pedicels; pedicels 7-12 mm long at anthesis. Calyx densely stellate-hairy, stellae $0.35-0.5 \mathrm{~mm}$ across, transparent or purple, lateral rays 7-8, central ray $0.5-1.5$ times as long as laterals, prickles absent or 1-5 per flower. Hypanthium campanulate, 3-4.5 mm long at anthesis; lobes attenuate, $3-9 \mathrm{~mm}$ long at anthesis. Corolla rotate, purple, 20-32 mm across, rotate. Filaments $0.8-1.0 \mathrm{~mm}$ long, glabrous; anthers 4.5-5.5 mm long. Ovary surface with stipitate glands and sparse to dense stellate hairs on the distal half; functional style 7.5-8.5 mm long, erect, with stipitate glands on the proximal half, and stellate hairs at extreme base, stellae with 8-9 lateral rays; stigma entire. Mature fruits 1-4 per inflorescence, globose, yellowish green, 13-17 mm diameter, pericarp 0.4-0.6 mm thick when fresh, surface with a few scattered stellate hairs. Fruiting calyx not noticeably accresent. Pedicels 8-11 $\mathrm{mm}$ long in fruit. Seeds white to pale yellow, 2.3-2.6 mm long. Fig. $3 \mathrm{~h}-\mathrm{k}$.

Distribution: known from numerous collections between Jervis Bay in New South Wales, and Mt Drummer in Victoria (Fig. 4).

Habitat: it inhabits tall eucalypt forests with a dense shrubby understorey, often bordering on rainforest, especially areas which have been logged or burnt.

Phenology: flowers from August to November. Fruits maturing in December-January.

Notes: S. silvestre differs from S. brownii by the broader juvenile and adult leaves, the lower leaf surface having a close tomentum with stellae $0.2-0.3 \mathrm{~mm}$ across (loose tomentum, stellae $0.3-0.6 \mathrm{~mm}$ across for S. brownii), pedicels $7-12 \mathrm{~mm}$ long at anthesis (13-18 mm for $S$. brownii) and the fruits only 13-17 mm diameter with a pericarp $0.4-0.6$ mm thick (18-29 mm diameter and pericarp 0.8-1.2 mm thick for S. brownii).

Conservation status: Applying the criteria of the IUCN (Anon. 1994), a category of 'Vulnerable' is proposed (Criteria B1 and B3 (b, c, d)). While the species has a relatively wide geographical range, its frequency is very low.

Etymology: from the Latin silvestris, meaning 'of the forest', in reference to its occurrence in tall dense eucalypt forest. 
Selected specimens (from 35 examined): New South Wales: South Coast: Currowan SF, c. $20 \mathrm{~km}$ NW of Batemans Bay, Pullen 8721 \& Story, 6 Dec 1973 (NSW); Clyde Mountain, Kings Highway, $19 \mathrm{~km}$ SE of Braidwood, Cameron s.n., 2 Nov 1974 (MEL); upslope from Marble Arch, Deua N.P., Lally 170, 24 Oct 1993 (NSW); 1 km N of Coondella Trig, Deua N.P., Rodd 6155 et al., 23 Jan 1991 (NSW); $0.5 \mathrm{~km}$ E of Plumwood Fire tower, Dampier SF, Albrecht 4802, 7 Oct 1991 (AD, BRI, MEL, NSW); Nerrigundah-Belowra road, Constable s.n., 16 Sep 1953 (NSW25623); Tarougra Forest road, 2 km E of Bodalla, Mullins 672, 7 Sep 1986 (NSW); Mt Dromedary, Tilba, Constable s.n., 14 Sep 1953 (NSW26483); Mumbulla Mtn, 10 miles [16 km] NNE of Bega, Constable 6806, 7 May 1966 (NSW); Kings Ridge road, Mimosa Rocks NP, P.J.Smith 19, 23 Sep 1983 (NSW); Big Jack Mtn, Coolangubra SF, Albrecht 2920, 21 Oct 1986 (MEL).

Victoria: Coolwater Ck catchment, Mt Drummer, 18.2 km due E of Cann River, Cameron 7010, 15 Oct 1976 (MEL).

\section{Solanum armourense A.R.Bean sp. nov.}

affinis Solano amblymero sed ab eo pilis stellatis multo minoribus (in ramulis pagina inferiore folii calyceque), indumento in pagina superiore folii densissimo, floribus minoribus et stylo parviore glandulis stipitatis tantum instructo differens.

Type: New South Wales: Central Tablelands: $0.5 \mathrm{~km} \mathrm{~S}$ of Mt Armour, Kanangra-Boyd N.P., via Oberon, A.R.Bean 17140, 19 December 2000 (holo BRI; iso CANB, MEL, NSW).

Shrub 1-1.8 m high. Fertile branchlets terete, grey or brown, tomentose, with very dense stellate hairs (obscuring branchlet), sparsely armed with prickles (1-10 per $\mathrm{dm}$ of branchlet) each 6-11 mm long, glabrous; stellae sessile to shortly stipitate, $0.1-0.2 \mathrm{~mm}$ across, lateral rays 6-8, central ray $0-0.5$ times as long as laterals. Juvenile leaves shallowly to deeply lobed, $3.5-6 \mathrm{~cm}$ long, $1.4-2 \mathrm{~cm}$ wide, sparsely prickly. Adult leaves elliptical in outline, entire or sinuate, lobes $0-2$ on each side, obtuse, lobing index 1-1.5; lamina 2.9-5.5 cm long, 0.6-1.3 cm wide, 4.2-5 times longer than broad, apex acute, basally dimidiate or symmetrical, oblique part $0-3 \mathrm{~mm}$ long, obliqueness index 0-5\%. Petioles $0.5-1.2 \mathrm{~cm}$ long, 17-26\% length of lamina, prickles absent. Upper leaf surface grey-green, flat between major veins; prickles absent, or present on midvein only; stellae dense to very dense (cores c. $0.05 \mathrm{~mm}$ apart), distributed throughout lamina, $0.1-0.15 \mathrm{~mm}$ across, sessile to shortly-stalked, lateral rays $6-8$, central ray $0-0.5$ times as long as laterals. Lower leaf surface yellowish-white, prickles absent; stellae densely packed in several layers, obscuring leaf surface, $0.15-0.2 \mathrm{~mm}$ across, more or less sessile (close tomentum), lateral rays 6-8, central ray $0-0.5$ times as long as lateral rays. Inflorescence pseudo-umbellate or sometimes pseudo-racemose with rachis present, 1-4-flowered, prickles absent from rachis and pedicels; pedicels 6-11 $\mathrm{mm}$ long at anthesis. Calyx densely stellate-hairy, stellae $0.15-0.2 \mathrm{~mm}$ across, transparent or purple, lateral rays $6-8$, central ray $0-0.5$ times as long as laterals, prickles absent or with 1-5 per flower. Hypanthium campanulate, 2.5-3.5 $\mathrm{mm}$ long at anthesis; lobes deltate to attenuate, $1.5-3 \mathrm{~mm}$ long at anthesis. Corolla rotate to shallowly lobed, $15-18 \mathrm{~mm}$ across. Filaments 1.1-1.5 mm long, glabrous; anthers 3.2-4.6 mm long. Ovary surface with stipitate glands on the distal half, stellate hairs absent; functional style $6.5-7 \mathrm{~mm}$ long, erect, with stipitate glands on the proximal half; stigma entire or obscurely bifid. Fruits 1-2 per inflorescence, globular, green, mature size unknown. Seeds not seen. Fig. $6 \mathrm{a}-\mathrm{c}$.

Distribution: S. armourense is confined to a relatively small area south-west of Sydney, from Yerranderie to Wombeyan (Fig. 4).

Habitat: S. armourense grows amongst other shrubs in eucalypt woodland, on steep rocky hillsides with shallow soil.

Phenology: flowers August-December; mature fruiting period unknown 
Notes: S. armourense is perhaps closest to $S$. amblymerum, but differs by the much smaller stellate hairs on the branchlets, lower leaf surface and calyx; very dense indumentum on the upper leaf surface; smaller flowers; and shorter style bearing stipitate glands only.

Conservation status: Applying the criteria of the IUCN (Anon. 1994), a category of 'Endangered' is proposed (Criteria B1 and B3(c,d)). The author could find only a few individuals of this species during traverses through the area of occurrence, despite the fact that most of the previous collection localities remain in a near-natural state.

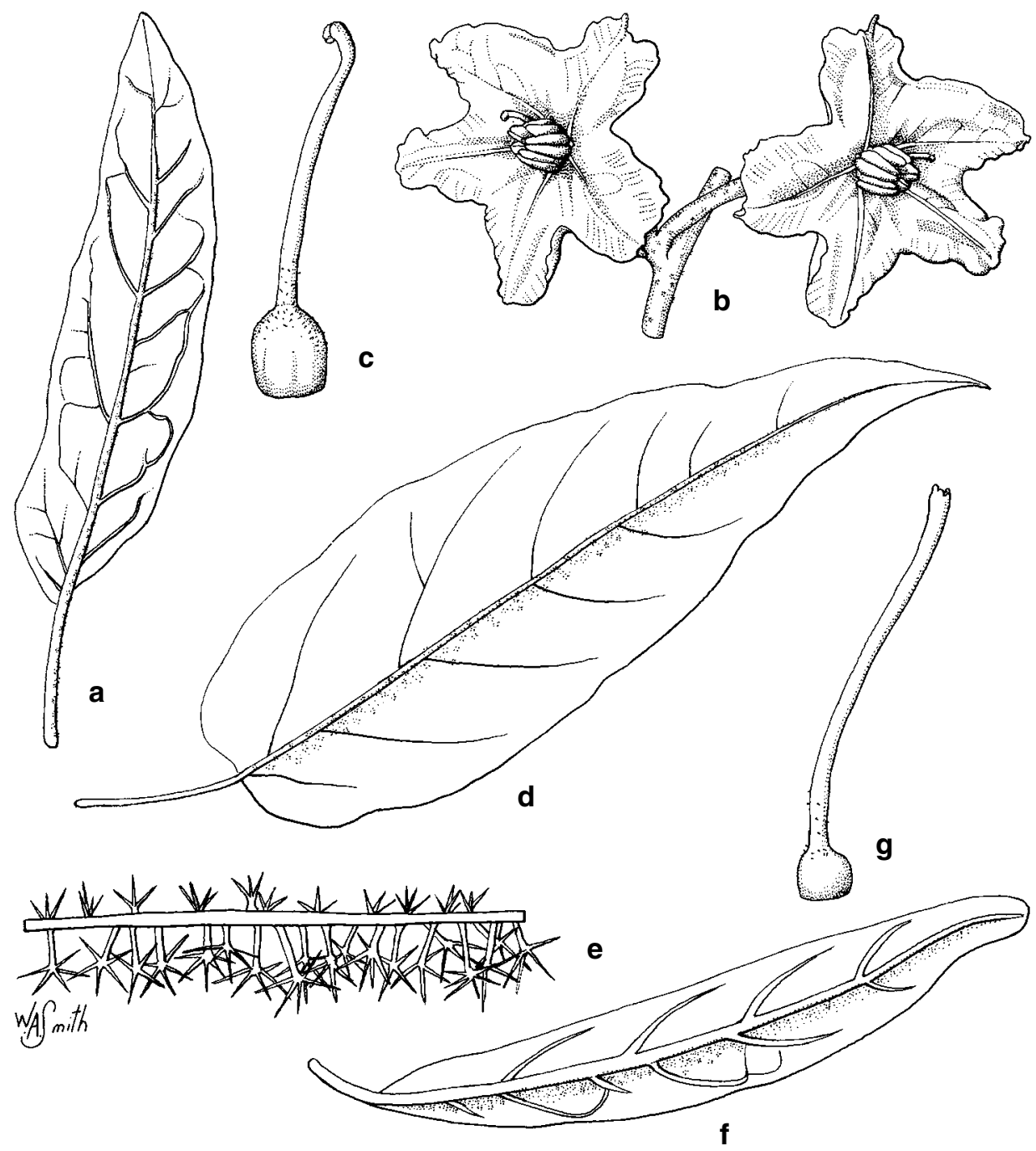

Fig. 6. Solanum armourense. $\mathbf{a}$, adult leaf $\times 2$; $\mathbf{b}$, inflorescence $\times 2$; $\mathbf{c}$, ovary and style $\times 10$. Solanum celatum. $\mathbf{d}$, adult leaf $\times 1$; e, cross-section of part of an adult leaf (adaxial surface at the top) $\times 30$. Solanum neoanglicum. $\mathbf{f}$, adult leaf $\times 2$; g, ovary and style $\times 6$. (a,b,c from Bean 17140; d, e from Rodway 3109; f, g from Coveny 5272.) 
Etymology: The epithet refers to the Armour Range, where the type was collected.

Selected specimens (from 7 examined): New South Wales: Central Tablelands: Mt Armour Range, near Mt Colong, Coveny s.n., 11 Sep 1967 (NSW464738); Yerranderie, Boorman s.n., Aug 1916 (BRI, MEL, NSW59679); Bullio to Wombeyan, Maiden s.n., Oct 1905 (BRI, NSW59678); Armour Range, E side of Mt Armour, Pickard 399 \& Pickard, 21 Sep 1969 (BRI, NSW); 4 km E of Jooriland HS, Blue Mountains NP, Kennedy 23 et al., 3 Oct 1990 (NSW).

\section{Solanum celatum A.R.Bean sp. nov.}

affinis Solano brownii sed ab eo folii pagina superiore erugata indumento denso praedita, radio centrali in folii pagina superiore 0.5-1-plo quam radiis lateralibus longiore (adversum 1-2-plo), fructibus minoribus et pilis stellatis in calyce minoribus differens.

Type: New South Wales: Central Coast: Yellow Rock, Albion Park, E.J. McBarron 14479, 1 October 1967 (holo BRI; iso NSW).

Shrub 1-2.5 m high. Fertile branchlets terete, grey to white, tomentose, with very dense stellate hairs (obscuring branchlet), sparsely armed with prickles ( $0-5$ per $\mathrm{dm}$ of branchlet) each 6-10 mm long, glabrous; stellae sessile to shortly stipitate, $0.25-0.35 \mathrm{~mm}$ across, lateral rays 6-8, central ray $0-0.5$ times as long as laterals. Juvenile leaves unknown. Adult leaves elliptical to lanceolate, without lobes; lamina 4.6-12.5 cm long, 1.5-3.5 cm wide, 2.6-3.6 times longer than broad, apex acute, base oblique or not, oblique part $0-5 \mathrm{~mm}$ long, obliqueness index 0-5\%. Petioles $0.8-2.4 \mathrm{~cm}$ long, $12-20 \%$ length of lamina, prickles rarely present. Upper leaf surface grey-green, flat between major veins; prickles sometimes present, on midvein only; stellae dense (cores $0.1-0.2 \mathrm{~mm}$ apart), distributed throughout lamina, $0.15-0.25 \mathrm{~mm}$ across, sessile to shortly-stalked, transparent, lateral rays $4-8$, central ray $0.5-1$ times as long as laterals. Lower leaf surface yellowish-white, prickles usually absent; stellae densely packed in several layers, often obscuring leaf surface, $0.2-0.4 \mathrm{~mm}$ across, with stalks $0.3-0.4 \mathrm{~mm}$ long (loose tomentum), lateral rays $6-8$, central ray $0.5-1$ times as long as laterals. Inflorescence pseudo-racemose, axis present, 4-7-flowered, prickles absent from rachis and pedicels; pedicels 15-20 mm long at anthesis. Calyx densely stellate-hairy, stellae 0.25-0.4 mm across, transparent or purple, lateral rays 6-8, central ray $0.5-1$ times as long as laterals. Prickles usually absent, rarely 1-5 per flower; hypanthium campanulate, 3-4 mm long at anthesis; lobes deltate to attenuate, $2.5-5 \mathrm{~mm}$ long at anthesis. Corolla 5-partite, rotate, purple, $24-32 \mathrm{~mm}$ across. Filaments $0.8-1.2 \mathrm{~mm}$ long, glabrous; anthers $5.0-6.5 \mathrm{~mm}$ long. Ovary surface with stipitate glands (and sometimes stellate hairs) on the distal half; functional style 8-9 mm long, erect, with stipitate glands (and sometimes stellate hairs) on the proximal half, stellae with 9-11 lateral rays; stigma entire. Mature fruits 1-4 per inflorescence, pale green, 13-16 mm diameter, pericarp $0.8-1 \mathrm{~mm}$ thick when fresh, surface glabrous. Fruiting calyx not noticeably accresent. Pedicels 15-23 mm long in fruit. Seeds white or pale yellow, 2.5-2.7 mm long. Fig. 6 d-e.

Distribution: endemic to New South Wales. It has been recorded from a restricted area from Wollongong to a little south of Nowra, and west to Bungonia Nature Reserve (Fig. 4).

Habitat: It grows in rainforest clearings, or in wet sclerophyll forest dominated by Eucalyptus. At Bungonia Nature Reserve it was recorded from open woodland on limestone.

Phenology: flowers August-October; fruits December-January.

Notes: S. celatum has been included with $S$. brownii for many years, although some herbarium labels refer to it as 'sp. aff. brownii'. It differs from $S$. brownii by features of the upper leaf surface: dense indumentum (stellae overlapping), not wrinkled 
between major veins; central ray of stellate hairs $0.5-1$ times as long as laterals (1-2 times in S. brownii; and by the smaller fruits, and smaller stellate hairs on the calyx.

Conservation status: Applying the criteria of the IUCN (Anon. 1994), a category of 'Endangered' is proposed (Criteria A2(e), B1, B2(e) and C1). Much of the area of occurrence of $S$. celatum has been cleared or grossly altered, and any uncleared areas are often swathed in dense patches of Lantana camara. During a recent field trip by the author, only one plant was found during 2.5 days of searching in the area of occurrence, including previous collection sites.

Etymology: The specific epithet is from the Latin celatum, meaning 'concealed', or 'kept secret'. This refers to the difficulty encountered by the author in finding this species in the field.

Selected specimens (from 37 examined): New South Wales: Central Coast: American Creek, Mount Kembla, Hamilton s.n., 15 Aug 1900 (NSW59740); Clover Hill road, c. $31 \mathrm{~km}$ SW of Wollongong, Jobson 868, 26 Sep 1989 (MEL, NSW); Macquarie Pass N.P., SW of Wollongong, Bean 17158, 21 Dec 2000 (BRI, MEL, NSW); Yellow Rock Creek, Albion Park, McBarron 12968, 21 Aug 1966 (NSW); Cambewarra Mtn, Maiden s.n., Sep 1905 (NSW59756); 5 miles [8 km] W of Barrengarry Pass, Rodway s.n., 18 Aug 1946 (NSW59675); Barbers Creek near Marulan, Rumsey 237, Oct 1899 (NSW); Bungonia Lookdown, Bungonia Recreation Reserve, Canning 4397, 13 Sep 1978 (CANB, NSW); Bungonia Cave reserve, Goulburn, Swan 5, 20 June 1974 (BRI). South Coast: Nowra, Rodway s.n., 1 Aug 1942 (NSW59673); Yerriyong, 8 miles [13 km] SW of Nowra, Hadley s.n., 25 Aug 1937 (NSW59672); Mt Bolwarra, 4 miles [6 km] W of Wandandian, Rodway 3109, 4 Aug 1940 (NSW).

\section{Solanum neoanglicum A.R. Bean sp. nov.}

affinis Solano celato sed foliis angustioribus, pilis stellatis in pagina inferiore folii radiis centralibus brevioribus instructis, pedicellis sub anthesi brevioribus et stylis tantum glandulas stipitatas gerentibus differens.

Type: New South Wales: Northern Tablelands: Ebor Falls Lookout, Ebor, A.R.Bean 17268, 7 January 2001 (holo BRI; iso MEL, NE, NSW).

Shrub 0.7-1.4 m high. Fertile branchlets terete, grey to purplish-grey, tomentose, with dense (branchlet visible) to very dense (hairs obscuring branchlet) stellate hairs, sparsely armed with prickles (0-3 per dm of branchlet) each 4-6 $\mathrm{mm}$ long, glabrous; stellae sessile to shortly stipitate, $0.25-0.4 \mathrm{~mm}$ across, lateral rays $7-8$, central ray $0-0.5$ times as long as laterals. Juvenile leaves broad-lanceolate in outline, with 1-3 pairs of shallow obtuse lobes, $7-9 \times 2-3 \mathrm{~cm}$, prickles present on upper leaf surface and often on lower surface. Adult leaves linear to narrowly lanceolate, lobes absent; lamina $3-9.6 \mathrm{~cm}$ long, $0.3-1.5 \mathrm{~cm}$ wide, 6-10 times longer than broad, apex obtuse or acute, basally dimidiate or symmetrical, oblique part $0-3 \mathrm{~mm}$ long, obliqueness index $0-4 \%$. Petioles 0.3-1.7 cm long, 11-21\% length of lamina, prickles absent. Upper leaf surface green to grey-green, flat between major veins; prickles present on midvein only, or absent; stellae moderate to dense (cores $0.1-0.3 \mathrm{~mm}$ apart), distributed throughout lamina, $0.15-0.25 \mathrm{~mm}$ across, sessile to shortly-stalked, lateral rays $4-8$, central ray $0-1$ times as long as laterals. Lower leaf surface white, prickles absent; stellae very dense (obscuring leaf surface) or dense (surface visible), 0.3-0.5 $\mathrm{mm}$ across, mostly longstalked (loose tomentum), lateral rays $7-8$, central ray $0-0.5$ times as long as laterals. Inflorescence pseudo-racemose, axis present, 1-4-flowered, prickles absent from rachis and pedicels; pedicels 10-13 mm long at anthesis. Calyx densely stellate-hairy, stellae $0.25-0.5 \mathrm{~mm}$ across, transparent or rarely purple, lateral rays $7-8$, central ray $0.5-1$ times as long as laterals, prickles absent. Hypanthium hemispherical to campanulate, 2-3 mm long at anthesis; lobes deltate, 2-3.5 mm long at anthesis. Corolla rotate, purple, $18-25 \mathrm{~mm}$ across. Filaments $0.7-1.2 \mathrm{~mm}$ long, glabrous; anthers $4-5 \mathrm{~mm}$ long. Ovary surface with stipitate glands on the distal half, stellate hairs few or absent; functional style 7.5-9 mm long, erect, with sparse stipitate glands on the proximal half; 
stigma lobed or entire. Mature fruits 1 per inflorescence, pale green, $14-17 \mathrm{~mm}$ diameter, pericarp $0.5-0.7 \mathrm{~mm}$ thick when fresh, surface glabrous. Fruiting calyx not noticeably accresent. Pedicels 17-23 mm long in fruit. Seeds white to pale yellow, 2.6-2.8 mm long. Fig. 6 f-g.

Distribution: occurs on the eastern half of the New England Tableland, N.S.W., from Guyra to Walcha (Fig. 4).

Habitat: apparently confined to rocky slopes and hills above 800 metres altitude, particularly on the edges of escarpments.

Phenology: flowers September-October; fruits maturing December-January.

Notes: $S$. neoanglicum is most closely related to $S$. celatum, but differs by the narrower leaves, shorter pedicels at anthesis, the shorter anthers, the styles bearing stipitate glands only, and the stellate hairs on the lower leaf surface having shorter central rays. It differs from $S$. brownii by the smaller fruits with a thinner pericarp, the dense indumentum on the upper leaf surface, and the stellae with shorter central rays on both leaf surfaces.

Conservation status: Applying the criteria of the IUCN (Anon. 1994), a category of 'Vulnerable' is proposed (Criteria B1, B3(c,d) and C2(a)). While much of the potential habitat is in an unaltered state, the species occurs only very sporadically within this habitat.

Etymology: The specific epithet is from the Latin neo- new and anglicus- English, referring to the New England Tableland of northern New South Wales, where the species is endemic.

Selected specimens (from 8 examined): New South Wales: Northern Tablelands: head of Big Scrub Ck, Guy Fawkes N.P., Floyd 1143, 10 Nov 1978 (NSW); near Backwater, Blakely et al., 30 Oct 1929 (NSW59703); Ebor, Werner s.n., 10 Sep 1969 (NSW88397); Wollomombi Falls, 36 km E of Armidale, Coveny 5272, 16 Oct 1973 (BRI, NSW); Moona Plains near Walcha, Crawford 47, Oct 1884 (MEL); Apsley Falls, Forsyth \& Cheel s.n., Oct 1900 (NSW72082); Tia Falls, Forsyth \& Cheel s.n., Oct 1900 (NSW59694).

\section{Acknowledgments}

I am grateful to the Directors of AD, BM, K, MEL and NSW for loan of specimens; Will Smith for the illustrations; Peter Bostock for the Latin diagnoses and distribution maps; the staff of Oberon NPWS for their assistance; Philip Sharpe for translating the German text of Domin's discussion on S. curvicuspe; and David Halford for reviewing the manuscript.

\section{References}

Anon. (1994). IUCN Red List Categories. (International Union for Conservation of Nature and Natural Resources: Switzerland).

Bentham, G. (1868). Solanum, in Flora Australiensis, Volume 4: 442-65. (L. Reeve \& Co.: London). Brown, R. (1810). Prodromus Florae Novae Hollandiae. (Richard Taylor: London).

Domin, K. (1913). Seventh Contribution to the Flora of Australia. Repert. Spec. Nov. Regni Veg. 12: 130-3.

Dunal, M. (1814). Solanum. in Poiret, Encyclopédie Méthodique, Botanique, Supplement 3. (Imprimeur-Libraire: Paris).

Dunal, M. (1852). Solanaceae. in A.L.P.P. DeCandolle, Prodromus 13(1): 1-690.

Field, B. (1825). Geographical Memoirs on New South Wales. (Murray: London). 
Roe, K.E. (1966). Juvenile forms in Solanum mitlense and S. blodgettii (Solanaceae) and their importance in taxonomy. Sida 2(5): 381-5.

Seithe, A. (1979). Hair types as taxonomic characters in Solanum, pp. 307-19. In: J.G.Hawkes, R.N.Lester \& A.D.Skelding (eds), The Biology and Taxonomy of the Solanaceae. (The Linnean Society of London: London).

Symon, D.E. (1981). A revision of the genus Solanum in Australia. J. Adel. Bot. Gard. 4: 1-367.

Vallance, T.G. (1990). Jupiter Botanicus in the bush: Robert Brown's Australian Field-work. Proc. Linn. Soc. New South Wales 112: 49-86.

Whalen, M.D., Costich, D.E. \& Heiser, C.B. (1981). Taxonomy of Solanum section Lasiocarpa. Gentes Herbarum 12(2): 41-129.

Manuscript received 14 May 2001

Manuscript accepted 28 September 2001 